DOI: $10.47743 /$ jss-2021-67-4-9

\title{
Tehnologia blockchain în executarea contractelor de publicitate comercială online
}

\author{
Blockchain Technology in the Performance \\ of Online Advertising Contracts
}

Aura-Elena Amironesei ${ }^{1}$

Rezumat: Relaţiile contractuale în spaţiul virtual au dobândit o nouă dimensiune amprentată inevitabil de avansul tehnologic fără precedent. Noile tehnologii tind să suplinească aportul uman în executarea contractelor, mai ales a celor cu executare de natură la rândul său virtuală, înlăturând totodată şi erorile, respectiv fraudele umane. Contractele de publicitate comercială online nu reprezintă o excepţie de la incidenţa neexecutărilor contractuale sau de la fraudarea părţilor prin diverse mijloace la rândul lor digitale. În acest context, noile tehnologii, în special tehnologia blockchain, se prefigurează drept o soluţie pentru executarea conformă a tuturor termenilor contractuali ce sunt încorporaţi într-un smart contract. Elementele contractuale clasice sunt transpuse în linii de cod ce devin legea părţilor în publicitatea online, iar criptomonedele sau tokens iau locul clasicului „preţ” plătit în bani.

Cuvinte-cheie: comerţ internaţional; publicitate comercială; smart contracts; blockchain

\begin{abstract}
The contractual relationships in virtual space have acquired a new dimension which is inevitably marked by the unprecedented technological advance. The new technologies tend to replace the human input in the execution of contracts, especially the ones involving a virtual performance, preventing human errors and frauds. Online advertising contracts do not stand as an exception from breaches of contract, neither from digital types of fraud. In this context, the new technologies, especially the blockchain technology, appear to be a solution for the full performance of the contractual terms that are embedded in a smart contract. The traditional contractual elements are transposed into lines of code which become the law of the parties in online advertising, and cryptocurrencies along with tokens become a replacement for the traditional price paid in money.
\end{abstract}

Keywords: international trade; commercial advertising; smart contracts; blockchain

\footnotetext{
${ }^{1}$ Doctorand, Facultatea de Drept, Universitatea „Alexandru Ioan Cuza” din Iaşi, e-mail: aura.amironesei@yahoo.com.
} 


\section{Introducere}

Apariţia tehnologiei blockchain şi ramificarea utilizării sale în domenii din ce în ce mai variate, a condus la inovarea unor domenii tradiţionale şi a reprezentat un răspuns la multe probleme ivite din cauza factorului uman implicat în anumite mecanisme. În acest proces de extindere, domeniile marketing-ului şi dreptului nu au fost ocolite, fiind prinse la rândul lor, de curând, în curentul „blockchain”. În cuprinsul prezentului articol vom analiza în ce mod şi de ce a fost implementată tehnologia blockchain în contractele de publicitate comercială online, ce soluţii a oferit la probleme existente în domeniu, ce elemente contractuale clasice au fost inovate şi dacă utilizarea sa reprezintă sau nu un avantaj cu perspective de viitor.

\section{Premisele existenţei tehnologiei blockchain în publicitatea comercială online}

Pătrunderea tehnologiei blockchain în peisajul publicităţii online nu s-a realizat odată cu apariţia acesteia, ci ulterior şi treptat, având la bază o serie de factori care au determinat şi facilitat modernizarea tehnologică a contractelor de publicitate comercială online. Printre aceşti factori se numără expansiunea industriei publicităţii online şi creşterea vertiginoasă a numărului şi formelor de fraudare a mecanismului publicităţii online.

\subsection{Expansiunea industriei publicităţii online}

După extinderea utilizării internetului, a avut loc o creştere fără precedent a furnizării serviciilor de publicitate online $e^{2}$ şi, în mod subsecvent, a veniturilor obţinute de către prestatorii de astfel de servicii, direct proporţional cu bugetele alocate acestei industrii de către profesionişti. Publicitatea în mediul virtual a devenit în timp o nouă formă de afacere larg răspândită ${ }^{3}$, cererea pentru astfel de servicii fiind în continuă creştere şi datorită eficienţei sale crescute, în special a celei de tip personalizat ${ }^{4}$ (targeted advertising ${ }^{5}$ ).

${ }^{2}$ European Parliament, Online advertising: the impact of targeted advertising on advertisers, market access and consumer choice, Study Requested by the IMCO committee, June 2021, DOI: https://doi.org/10.2861/80 | QA-02-21-683-EN-N, [Online] la https://www.europarl.europa.eu/RegData/etudes/STUD/2021/662913/IPOL_STU(2021)6629 13_EN.pdf, accesat 30.11.2021, p. 12 și PwC, Macrotrends. Global revenue - growth by segments, [Online] la https://www.pwc.com/gx/en/industries/tmt/media/outlook/segmentfindings.html, accesat 30.11.2021.

${ }^{3}$ Z. Pooranian, M. Conti, H. Haddadi, R. Tafazolli, Online Advertising Security: Issues, Taxonomy, and Future Directions, în IEEE Communications Surveys \& Tutorials, vol. XX, vo. NN, XX, 2020, https://www.researchgate.net/publication/342027116_Online_ Advertising_Security_Issues_Taxonomy_and_Future_Directions, accesat 30.11.2021, p. 1.

${ }^{4}$ Ibidem.

${ }^{5}$ C. T. Ungureanu, Drept international privat european in raporturi de comert international, Editura Hamangiu, București, 2021, p. 371. 
Această expansiune, catalogată drept un $b^{\circ} o^{6}$, a ajuns să plăsmuiască un real ecosistem al publicităţii online, alcătuit din lanţul contractual în baza căruia serviciile specifice sunt prestate. În respectivul ecosistem regăsim toate părţile contractuale drept actori cu roluri bine definite, alături de toate acţiunile, respectiv drepturile şi obligaţiile contractuale, ce se regăsesc în cuprinsul contractelor.

Odată cu creşterea cererii şi a ofertei publicitare, ecosistemul a devenit din ce în ce mai complex, cu mai mulţi actori (în prezent pot fi până la aproximativ 23 de participanţi implicaţi ${ }^{7}$ ) şi mai multe relaţii, mecanisme şi acţiuni. Acest ecosistem trece de frontierele naţionale, manifestându-se la un nivel internaţional, în comerţul internaţional. Caracterul tranfrontalier proaspăt dobândit a generat dificultăţi la încheierea şi executarea contractelor de publicitate comercială online, inclusiv la nivel de plată a preţului, astfel că a fost nevoie de soluţii pentru înlăturarea impedimentelor din naşterea şi derularea relaţiei contractuale.

Complexitatea ecosistemului contractual aduce cu sine şi o serie de provocări pentru părţile principale implicate, doi profesionişti ${ }^{8}$, şi anume marketer/advertiser şi publisher ${ }^{9}$, între ele fiind o reţea de publicitate, cunoscută drept ad network ${ }^{10}$, parte din ad exchange ${ }^{11}$. Ecosistemul are la bază un mecanism relativ simplu: un marketer (înţeles drept participant la comerţul internaţional care doreşte să îşi promoveze produsele prin intermediul publicităţii online) contractează cu un publisher furnizarea unor servicii de publicitate online (publisher-ul fiind cel care prestează serviciile sub diverse forme, în funcţie de obiectul contractului). După

${ }^{6} \mathrm{PwC}$, Is blockchain the answer to digital advertising's trust gap?, 2019, [Online] la https://www.pwc.com/us/en/industries/tmt/assets/2019-blockchain-in-advertising.pdf, accesat 30.11.2021, p. 2.

${ }^{7}$ Ibidem. Pentru o imagine vizuală a celor potențial implicați în publicitatea online, a se vedea https://www.slideshare.net/tkawaja/luma-display-ad-tech-landscape-2010-1231, accesat 30.11.2021.

${ }^{8}$ Conform art. 3 din C. civ., un profesionist este cel care exploatează o întreprindere, acțiune definită drept „exercitarea sistematică, de către una ori mai multe persoane, a unei activităţi organizate ce constă în producerea, administrarea sau înstrăinarea de bunuri ori în prestarea de servicii, indiferent dacă are ori nu un scop lucrativ".

${ }^{9}$ Z. Pooranian, M. Conti, H. Haddadi, R. Tafazolli, op. cit., p. 3.

${ }^{10}$ Idem, p. 1. Pentru mai multe detalii despre ad network, a se vedea, MoPub Inc., Understanding ad networks, 2017, [Online] la https://www.mopub.com/content/ dam/mopub-aem-twitter/migration/39639-mopub-understanding-ad-networks.pdf, accesat 30.11.2021.

11 Z. Pooranian, M. Conti, H. Haddadi, R. Tafazolli, op. cit., p. 3. Pentru mai multe detalii despre ad exchange, a se vedea, S. Muthukrishnan, Ad Exchanges: Research Issues, în Leonardi S. (eds), Internet and Network Economics, WINE, Lecture Notes in Computer Science, vol 5929. Springer, Berlin, Heidelberg, 2009, https://doi.org/10.1007/978-3-642-108419_1, [Online] la http://www.eecs.harvard.edu/cs286r/courses/fall09/papers/start2.pdf, accesat 30.11.2021. Pentru mai multe detalii despre diferența dintre ad network și ad exhange, a se vedea, Open X, Ad networks vs ad exchanges: how they stack up, 2010, [Online] la https:// www.cs.princeton.edu/courses/archive/spring13/cos448/web/docs/adnets_vs_exchanges.pdf, accesat 30.11.2021. 
încheierea contractului, publisher-ul afişează reclamele cu produsele şi/sau serviciile marketer-ului unui consumator. Datele obţinute din interacţiunea consumatorului cu acel conţinut publicitar afişat sunt transmise apoi, de către publisher, către marketer. În toată această construcţie contractuală, pe de o parte, marketer-ul trebuie să aleagă într-un mod cât mai eficient publisher-ul (şi, implicit, ecosistemul pentru lanţul contractual). De cealaltă parte, publisher-ul trebuie să atingă standardele impuse de marketer, să ofere informaţii cu un grad ridicat de acuratețe înapoi către marketer, să îndeplinească şi aşteptările consumatorilor în materie de conţinut publicitar ce le este afişat şi să asigure mecanisme de informare cu privire la prelucrarea datelor cu caracter personal.

În final, utilizarea la un nivel fără precedent a publicităţii online, prin diverse modalităţi de realizare a acesteia ${ }^{12}$ (adică o multitudine de obiecte contractuale), are drept consecinţă şi dificultatea unui profesionist (marketerul/advertiserul) în a aprecia, în cazul în care desfăşoară o campanie publicitară extinsă pe mai multe domenii ale publicităţii online (banner ads ${ }^{13}$, video ${ }^{14}$, influencer marketing ${ }^{15}$ etc.), în mod concret, care tip de publicitate este cel mai eficient şi ce conţinut publicitar a avut cel mai mare impact asupra consumatorilor ${ }^{16}$. În mod corelativ, din cauza aceleiaşi diversificări a instrumentelor publicitare online, este dificil pentru un profesionist (marketer) să afle dacă şi prin care tip de publicitate sau ce cocontractant (publisher) a încălcat prevederile legislaţiei în materie de drepturi cu caracter personal, atunci când apelează la mai multe mijloace de a realiza publicitatea online. Astfel de încălcări îl prejudiciază în mod cert şi direct, din moment ce reclamele sale sunt asociate cu brand-ul să $u^{17}$. Prejudiciul este mai mare atunci când consumatorii sunt cetățeni europeni pentru că aceştia se bucură de reglementări în favoarea lor mult mai riguroase, care le conferă o protecţie sporită a datelor cu caracter personal şi care îi protejează împotriva unor practici comerciale neloiale în care publicitatea online este implicată.

${ }^{12}$ C. T. Ungureanu, op. cit., pp. 369-371.

${ }^{13}$ European Parliament, Online advertising: the impact of targeted advertising on advertisers, market access and consumer choice, ..., p. 17.

${ }^{14}$ Ibidem.

${ }^{15}$ Pentru mai multe detalii, a se vedea, Z. Kadekova, M. Holienčinová, Influencer marketing as a modern phenomenon creating a new frontier of virtual opportunities în Communication Today, no. 9, 2018, pp. 90-104, [Online] la https://www.researchgate.net/ publication/329247338_Influencer_marketing_as_a_modern_phenomenon_creating_a_ne w_frontier_of_virtual_opportunities, accesat 30.11.2021.

${ }^{16} \mathrm{PwC}$, Is blockchain the answer to digital advertising's trust gap?, ..., p. 4.

${ }^{17}$ M. Išoraitè, Raising Brand Awarenees Through The Internet Marketing Tools, în Independent Journal of Management \& Production (IJM\&P), v. 7, n. 2, April - June 2016, DOI:https://doi.org/10.14807/ijmp.v7i2.391, [Online] la https://dialnet.unirioja.es/descarga/ articulo/5680392.pdf, accesat 30.11.2021, p. 336. 


\subsection{Ad fraud}

Având în vedere cuantumul resurselor financiare implicate în mecanismul publicităţii online, frauda s-a strecurat inevitabil ${ }^{18}$ în interiorul său. Frauda este favorizată şi de lipsa de transparenţă a ad network, alături de complexitatea sa ${ }^{19}$, care reprezintă o premisă pentru breşe de securitate.

În publicitatea personalizată ${ }^{20}$, predominantă în mediul online, datele pe care consumatorul le furnizează din urma interacţiunii sale cu un conţinut publicitar se cuantifică drept ad's impact. Acestea sunt colectate de către publisher şi transmise către marketer, denumit şi ad buyer ${ }^{21}$. In baza acestor date este măsurat impactul asupra consumatorilor a serviciilor de publicitate prestate şi deseori este determinată şi valoarea contractului (cu cât rezultatele arată că reclamele au ajuns la consumatorii ideali pentru respectivele produse şi că au existat interacţiuni, chiar conversii ${ }^{22}$ în urma reclamelor, cu atât serviciul prestat este mai valoros, respectiv mai scump).

Statisticile obţinute în urma interacţiunii consumatorilor cu reclamele au o importanţă deosebită în performance marketing ${ }^{23}$, unde preţul pe care un marketer îl plăteşte este stabilit în funcţie de rezultate cuantificabile. Există mai multe modalităţi de a calcula preţul contractului în contractele online de publicitate: cost per mille $e^{24}$, numit şi cost per thousands ${ }^{25}$ (preţ fix stabilit pentru o mie de ad impressions); cost per click ${ }^{26}$ (preţ stabilit în funcţie de numărul de click-uri); cost per action $^{27}$ (se stabileşte în prealabil o acţiune ce se doreşte a fi realizată de către

${ }^{18}$ Z. Pooranian, M. Conti, H. Haddadi, R. Tafazolli, op. cit., p. 1.

${ }^{19}$ Ibidem.

${ }^{20}$ Pentru mai multe detalii, a se vedea, A. Bleier, M. Eisenbeiss, Personalized Online Advertising Effectiveness: The Interplay of What, When, and Where, July 2015, Marketing Science, 2015, DOI: https://doi.org/10.1287/mksc.2015.0930, [Online] la https://www.researchgate.net/publication/274371236_Personalized_Online_Advertising_E ffectiveness_The_Interplay_of_What_When_and_Where, accesat 30.11.2021.

${ }^{21} \mathrm{PwC}$, Is blockchain the answer to digital advertising's trust gap?, ..., p. 3.

${ }^{22}$ Conversiile se referă la transformarea unei simple interacțiuni cu conținutul publicitar, în decizii comerciale de a achiziționa produsul sau serviciul promovat (transformarea unui utilizator în consumator).

${ }^{23}$ Acesta se referă la marketing-ul în care prețul contractelor este determinat în baza rezultatelor campaniei de marketing. Pentru mai multe detalii, a se vedea, Zeropark Blog, What Is the Difference Between CPM, CPC, CPL, CPA and Other Performance Marketing Pricing Models?, 28th of May, 2021, [Online] la https://zeropark.com/blog/difference-cpmcpc-cpl-cpa-performance-marketing-pricing-models/, accesat 30.11.2021.

24 [Online] la https://www.marketingterms.com/dictionary/cpm/, accesat 30.11.2021.

${ }^{25}$ W. Kenton, Cost Per Thousand (CPM), Investopedia, October 29, 2020 [Online] la https://www.investopedia.com/terms/c/cpm.asp, accesat 30.11.2021.

${ }^{26}$ Pentru mai multe detalii, a se vedea, A. Jain, S. Khan, Optimizing Cost per Click for Digital Advertising Campaigns, în Lattice, Volume 2, Issue 2, 2021, [Online] la https://arxiv.org/pdf/2108.00747.pdf, accesat 30.11.2021, pp. 16-21.

${ }^{27}$ Pentru mai multe detalii, a se vedea, H. Nazerzadeh, A. Saberi, R. Vohra, Dynamic Cost-Per-Action Mechanisms and Applications to Online Advertising, în Internet 
consumatori, iar preţul este stabilit în funcţie de numărul de acţiuni realizate - e.g. să acceseze site-ul profesionistului sau chiar să cumpere produsul sau serviciul promovat prin reclamă ${ }^{28}$ ); cost per engagement ${ }^{29}$ (preţul este stabilit în funcţie de numărul de interacţiuni de o anumită calitate prestabilită de către advertiser - e.g. consumatorul care îi accesează site-ul să navigheze pe acesta cel puțin 15 secunde); cost per conversion ${ }^{30}$ (preţ stabilit în funcţie de numărul de consumatori transformaţi în clienţi în urma interacţiunii cu conţinutul publicitar).

Toate variabilele în baza cărora se poate stabili calculul preţului contractului pot avea valori modificate faţă de cele reale sau autentice din cauza unor fraude extrinseci ecosistemului precum: bots ${ }^{31}$, care realizează în special acţiuni de click, conducând la click spam; click farms ${ }^{32}$, care conduc tot la click spam; conturi false de consumatori care realizează interacţiuni şi acţiuni; programe de calculator frauduloase; reclame plasate pe Ghost Sites ${ }^{33}$ (site-uri web incorecte sau inexistente), care generează impression spam ${ }^{34}$ fiindcă acel conţinut publicitar este afişat pe pagini care sunt disponibile şi pentru consumatori ${ }^{35}$ (pagini care nu sunt vizualizate public). În cazul click-spam, care este parte din click fraud $^{36}$ (practica de a genera click-uri frauduloas ${ }^{37}$ ), au loc click-uri invalide, nelegitime. Un click fraudulos este acela făcut cu intenţie şi rea-credinţă, urmărind un scop ilicit, în afara cadrului contractual. Acestea pot fi făcute manual, de către oameni ${ }^{38}$ sau automat, prin intermediul unor programe de calculator ${ }^{39}$, numite în general

Monetization - Online Advertising, April 21-25, Beijing, China, 2008, [Online] la https://web.stanford.edu/ saberi/cpa.pdf, accesat 30.11.2021.

${ }^{28}$ N. Daswani, C. Mysen, V. Rao, S. Weis, K. Gharachorloo, S. Ghosemajumder, the Google Ad Traffic Quality Team, Online Advertising Fraud, 2007, [Online] la http://citeseerx.ist.psu.edu/viewdoc/download?doi=10.1.1.135.2077\&rep=rep1\&type=pdf, accesat 30.11.2021, p. 3.

${ }^{29}$ Pentru mai multe detalii, a se vedea, Content Strategy Studio, Brand Engagement in the Participation Age, Whitepaper, February 2014, [Online] la https://think.storage.googleapis.com/docs/brand-engagement-in-participation-

age_research-studies.pdf, accesat 30.11.2021.

${ }^{30}$ Pentru mai multe detalii, a se vedea, [Online] https:/www.facebook.com/business/ help/373829586327518, accesat 30.11.2021.

${ }^{31}$ N. Daswani, C. Mysen, V. Rao, S. Weis, K. Gharachorloo, S. Ghosemajumder, and the Google Ad Traffic Quality Team, op. cit., p. 15.

32 [Online] la https://en.wikipedia.org/wiki/Click_farm, accesat 30.11.2021.

${ }^{33} \mathrm{PwC}$, Is blockchain the answer to digital advertising's trust gap?, ..., p. 5. Ghost Sites se referă la site-uri inexistente sau incorecte, care apar la final drept site-uri viabile pentru care advertiser-ul plătește.

${ }^{34}$ N. Daswani, C. Mysen, V. Rao, S. Weis, K. Gharachorloo, S. Ghosemajumder, and the Google Ad Traffic Quality Team, op. cit., p. 3, 8.

${ }^{35}$ Idem, p. 3.

${ }^{36}$ Z. Pooranian, M. Conti, H. Haddadi, R. Tafazolli, op. cit., p.. 8.

${ }^{37}$ N. Daswani, C. Mysen, V. Rao, S. Weis, K. Gharachorloo, S. Ghosemajumder, and the Google Ad Traffic Quality Team, op. cit., p. 9.

${ }^{38}$ Idem, p. 11.

${ }^{39}$ Idem, p. 9. 
clickbots $^{40}$. Indiferent de modalitate, se consideră că sunt o formă de criminalitate cibernetică $^{41}$.

O formă particulară de click spam este competitor clicking ${ }^{42}$, care apare atunci când un concurent, direct sau indirect, dă click-uri pe reclamele concurentului său pentru a-l face să cheltuie mai mult din propriul buget şi pentru a diminua concurenţa. În momentul în care un profesionist interacţionează cu reclamele concurentului său, el nu este un consumator vizat, iar preţul dat pentru interacţiunile respective reprezintă în fapt o pagubă, obiectivul sumelor alocate activităţii de marketing nefiind atins. În plus, are loc în acelaşi timp şi o consumare resurselor financiare destinate acţiunilor de promovare, astfel că majoritatea consumatorilor de pe piaţa celor doi concurenţi vor vizualiza mai mult reclamele profesionistului cu un comportament neloial pentru că acestuia i-a rămas buget şi sistemului îi apare că ar fi fost deja afişate consumatorilor doar reclamele concurentului (si se atinge target-ul de clicks), rămânând să fie afişate în continuare doar cele ale primului profesionist.

Mai există, tot în sfera click spam, şi publisher click inflation ${ }^{43}$, situaţie în care chiar publisher-ul dă click pe reclamele de pe propria sa pagină pentru a primi mai mulţi bani cu titlu de preţ al contractului.

Frauda poate proveni şi de la advertiser, nu numai de la concurenţi, terţi, alţi participanţi în ecosistemul publicitar sau de la publisher. $\mathrm{O}$ astfel de fraudă poate avea loc atunci când deşi publisher-ul a avut o executare conformă, advertiser-ul refuză plata preţului şi invocă neexecutarea contractuală ${ }^{44}$. De asemenea, acesta mai poate găsi şi alte metode prin care să micşoreze în mod ilicit preţul ce trebuie achitat.

În anul 2018, prejudiciul cauzat de frauda în executarea contractelor de publicitate comercială a fost de aproximativ 19 miliarde de dolari ${ }^{45}$. Pe termen lung, astfel de fraude se reflectă grosso modo în indicele ROI (return on investment ${ }^{46}$ ) sau, mai specific, ROMI (return on marketing investment ${ }^{47}$ ), care se calculează prin

${ }^{40}$ Z. Pooranian, M. Conti, H. Haddadi, R. Tafazolli, op. cit., p. 8.

${ }^{41}$ Ibidem.

${ }^{42}$ N. Daswani, C. Mysen, V. Rao, S. Weis, K. Gharachorloo, S. Ghosemajumder, and the Google Ad Traffic Quality Team, op. cit., p. 9.

${ }^{43}$ Ibidem.

${ }^{44}$ SaTT Token, Smart Advertising Transaction Token (SaTT), White Paper, V.6.2, 06/01/2021, [Online] la https://satt-token.com/files/ico_satt_en.pdf, accesat 30.11.2021, p. 15.

${ }^{45} \mathrm{PwC}$, Is blockchain the answer to digital advertising's trust gap?, ..., p. 2.

${ }^{46}$ M. Zamfir, M. Manea, L. Ionescu, Return On Investment - Indicator for Measuring the Profitability of Invested Capital, în Valahian Journal of Economic Sciences vol. 7(2), 2016, DOI: https://doi.org/10.1515/vjes-2016-0010, [Online] la https:/www.researchgate.net/ publication/309516326_Return_On_Investment_-_Indicator_for_Measuring_the_ Profitability_of_Invested_Capital, accesat 30.11.2021, p. 80.

${ }^{47}$ Pentru mai multe detalii, a se vedea, https://www.marketingevolution.com/ marketing-essentials/marketing-roi. 
raportare la veniturile obţinute în urma unor investiţii ${ }^{48}$ în activitatea de marketing a profesionistului. Se consideră că cel mai mare ROI este generat în prezent de publicitatea online, în detrimentul ROI generat de publicitatea tradiţională ${ }^{49}$.

În publicitatea comercială online, în special cea de tip personalizat, causa remota a oricărui contract este ca reclamele (conţinutul publicitar) să fie livrate direct doar consumatorilor interesaţi (determinaţi pe baza preferinţelor lor), care au potenţialul de a interacţiona cu acel conţinut şi chiar de a fi convertiţi în consumatori (să existe o probabilitate mare de a fi realizate conversii). Totuşi, este cu adevărat dificil să fie creat un conţinut publicitar care să fie afişat cu exactitate întocmai unui consumator „perfect”. Această incertitudine în privinţa atingerii scopului şi satisfacerii causa remota ${ }^{50}$ are un real impact asupra preţului contractelor de publicitate comerciale, unele fiind supraevaluate. Astfel, contractele ajung să încorporeze adesea şi un element de alea în ceea ce priveşte executarea obligaţiilor prestatorului de servicii de publicitate online (publisher).

În cazul publicităţii comerciale online, un contract de publicitate comercială executat cu bună-credinţă şi integral, conform tuturor criteriilor şi standardelor contractuale stabilite, ar trebui să ducă la atingerea cauzei expuse anterior şi să genereze astfel o valoare cât mai mare a $\mathrm{ROI}^{51}$, ceea ce ar însemna că tot conţinutul publicitar a fost livrat acelor consumatori perfecţi care au avut interacţiuni şi chiar au realizat conversii, adică au luat decizii comerciale în baza reclamelor, în sensul de a achiziţiona produsele sau serviciile promovate, generând astfel venituri profesionistului.

În plus, se observă că în ecosistemul publicitar are lor un transfer constant de „materie”, materia fiind în fapt reprezentată de diverse date, în special datele cu caracter personal ale potenţialilor consumatori. Pentru executarea unui contract de publicitate comercială online, datele furnizate atât de către publisher, cât şi de alţi actori implicaţi (precum platforme online de intermediere sau de prelucrare a datelor cu caracter personal în scopuri publicitare) sunt constant predate de la un participant la altul, într-o manieră secvenţională, şi se poate ajunge până la peste 20 de astfel de transferuri date într-un lanţ contractual complet. La fiecare astfel de transfer, setul de date poate suferi modificări, erori, diminuări, alterări, producându-se fie rupturi în lanţul contractual, fie chiar fraude (ca urmare a erorilor sau de sine stătătoare) sau încălcări ale legislaţiei cu privire la protecţia datelor cu caracter personal. În ecosistem există participanţi întocmai cu rolul de a preveni

${ }^{48}$ P. Koen, D. Reibstein, Challenges in Measuring Return on Marketing Investment: Combining Research and Practice Perspectives, Review of Marketing Research vol. 6. Emerald Group Publishing Limited, Bingley, 2009, DOI: https://doi.org/10.1108/S15486435(2009)0000006009, p. 107.

${ }^{49}$ N. Daswani, C. Mysen, V. Rao, S. Weis, K. Gharachorloo, S. Ghosemajumder, and the Google Ad Traffic Quality Team, op. cit., p. 4.

${ }^{50}$ C. T. Ungureanu, A. I. Toader, Drept civil. Partea generală. Persoanele, Editura Hamangiu, București, 2019, p. 224.

51 Z. Pooranian, M. Conti, H. Haddadi, R. Tafazolli, op. cit., p. 4. 
astfel de erori, respectiv fraude ${ }^{52}$, făcându-l şi mai complex, dar fără a oferi o siguranţă integrală cu privire la atingerea scopului implicării lor. Lipsa de încredere cu privire la securitatea, integritatea şi corectitudinea datelor (securitate şi în sens de transfer) conduce la un comportament ezitant în privinţa distribuirii datelor, ceea ce are potenţialul de a frâna evoluţia şi densificarea contractelor de publicitate comercială.

Conceptul de ad fraud ar putea fi înţeles, într-o manieră extensivă, şi drept erori, inconsecvenţe sau limitări ale publicităţii online faţă de consumatori (o formă de neexecutare parţială sau executare neconformă a contractului de publicitate comercială). Sub umbrela acestei interpretări, s-ar regăsi drept ad fraud şi furnizarea unui conţinut publicitar neconcordant cu preferinţele consumatorilor şi într-o manieră abuzivă, agasantă, expunerea unor reclame cu potenţial de a frauda alegerea consumatorilor sau care încorporează elemente nelegale, reprezintă prin ele însele produsul unor fapte ilicite sau redirecţionează către site-uri sau profesionişti de neîncredere.

\section{Smart contracts în publicitatea comercială online}

În continuare, vom analiza emergenţa smart contracts în publicitatea online, ele fiind mijlocul prin care tehnologia blockchain a pătruns în sfera executării contractelor de publicitate comercială online.

\subsection{Repere tehnice şi juridice privind smart contracts}

Tehnologia blockchain a fost creată tocmai pentru a înregistra tranzacţii ${ }^{53}$ într-un mod descentralizat ${ }^{54}$ (printr-o reţea distribuită ${ }^{55}$ ), verificat ${ }^{56}$ şi securizat, având totodată rolul şi de a le executa ${ }^{57}$. Prin blockchain, părţile unui contract pot trimite, primi şi stoca informaţ̧ii într-un sistem distribuit de tip peer-to-peer ${ }^{58}(\mathrm{P} 2 \mathrm{P})$,

${ }^{52} \mathrm{PwC}$, Is blockchain the answer to digital advertising's trust gap?, ..., p. 2.

${ }^{53}$ M. Corrales, M. Fenwick, H. Haapio, Digital Technologies, Legal Design and the Future of the Legal Profession în M. Corrales, M. Fenwick, H. Haapio (eds.), Legal tech, Smart contracts and Blockchain, Springer Nature Singapore Pte Ltd., 2019, p. 2.

${ }^{54}$ M. Atzori, I. Sistemi, Blockchain technology and decentralized governance: Is the state still necessary?, în Journal of Governance and Regulation 6(1), March 2017, DOI: https://doi.org/10.22495/jgr_v6_i1_p5, [Online] la https://www.researchgate.net/ publication/315919685_Blockchain_technology_and_decentralized_governance_Is_the_sta te_still_necessary, accesat 30.11.2021, p. 45.

${ }^{55}$ R. Zhang, R. Xue, L. Liu, Security and Privacy on Blockchain în ACM Comput. Surv. 1, 1, Article 1, January, https://doi.org/10.1145/3316481, [Online] la https:// arxiv.org/pdf/1903.07602.pdf, accesat 30.11.2021, p. 1.

${ }^{56}$ M. Corrales, M. Fenwick, H. Haapio, op. cit., p. 3.

${ }^{57}$ R. Zhang, R. Xue, L. Liu, op. cit., p. 3.

${ }^{58}$ Rawat D. B., Vijay Chaudhary V., Doku R. , Blockchain Technology: Emerging Applications and Use Cases for Secure and Trustworthy Smart Systems, în Journal of Cybersecurity and Privacy no. 1(1), 2021, [Online] la https://www.mdpi.com/ 2624800X/1/1/2/pdf, accesat 30.11.2021, https://doi.org/10.3390/jcp1010002, p. 8. 
aflat simultan pe mai multe computere ${ }^{59}$. Tranzacţiile valide sunt întregistrate succesiv $^{60}$ în blocks care se înlăţuiesc, formându-se un lanţ de blocks, adică blockchain. Liantul principal este reprezentat de hash, valoarea unică atribuită fiecărui block, care este apoi preluată în block-ul care urmează după şi cu care se înlănţuieşte ${ }^{61}$. Fiind descentralizat, blockchain nu se află sub controlul unei singure persoane ${ }^{62}$, ceea ce reprezintă un avantaj, aspect pe care îl vom discuta în continuare.

Un tip de tranzacţii ce pot fi „,̂nregistrate” folosind tehnologia blockchain sunt smart contracts. Fiind construite în baza acestei tehnologii, ajung să împrumute o serie din caracteristicile sale, rezultând o formă mai complexă decât smart contracts clasice. Acestea au la bază algoritmi şi presupun executarea contractelor de natură comercială ${ }^{63}$, fară intervenţia umană, în mod automat, în conformitate cu clauzele contractuale convenite (cuprinse în codul algoritmului).

Diferenţa între smart contracts şi online contracts (cele de tip click-wrap ${ }^{64}$ ) constă nu numai în modalitatea de încheiere, ci şi în însăşi executarea contractului. În timp ce online contracts cuprind doar prevederile contractuale, fără a primi date cu privire la executarea contactului şi fără a verifica încălcările obligaţiilor contractuale, smart contracts se execută automat, având acces la informaţii cu privire la modul de executare a prevederilor contractuale cuprinse în codul algoritmului ${ }^{65}$.

Smart contracts sunt imuabile ${ }^{66}$ şi irevocabile ${ }^{67}$, ceea ce înseamnă că este exclusă încheierea unor acte adiţionale sau modificarea lor ulterioară. În momentul în care a fost greşit codul unui contract, se poate crea alt contract în care să intre aceleaşi părţi. Smart contracts nu pot fi alterate, falsificate şi nici şterse ${ }^{68}$, rămânând mereu înregistrate în acelaşi block (blockchain funcţionează şi ca o arhivă de contracte $\left.^{69}\right)$, ceea ce contribuie la creşterea gradului de încredere ${ }^{70}$ şi la asigurarea unui înalt nivel de transparenţă contractuală ${ }^{71}$.

${ }^{59}$ D. Jaina, M. K. Dashb, A. Kumarc, S. Luthra, How is Blockchain used in marketing: A review and research agenda, în International Journal of Information Management Data Insights, https://doi.org/10.1016/j.jjimei.2021.100044, [Online] la https://www.sciencedirect.com/science/article/pii/S2667096821000379, accesat 30.11.2021, p. 2.

${ }^{60}$ M. Corrales, M. Fenwick, H. Haapio, op. cit., p. 3.

${ }^{61}$ R. Zhang, R. Xue, L. Liu, op. cit., p. 3.

${ }^{62}$ Ibidem.

${ }^{63}$ Idem, p. 5.

${ }^{64}$ C. T. Ungureanu, Dreptul comerțului internațional, Editura Hamangiu, București, 2018, pp. $160-161$.

${ }^{65}$ M. Corrales, M. Fenwick, H. Haapio, op. cit., p. 20.

${ }^{66}$ D. Jaina, M. K. Dashb, A. Kumarc, S. Luthra, op. cit., p. 1.

${ }^{67}$ M. Corrales, M. Fenwick, H. Haapio, op. cit., p. 23.

${ }^{68}$ Idem, p. 3.

${ }^{69}$ R. Zhang, R. Xue, L. Liu, op. cit., p. 3.

${ }^{70}$ M. Corrales, M. Fenwick, H. Haapio, op. cit., p. 3.

${ }^{71}$ Idem, p. 4. 
Prin intermediul lor, liniile de $\operatorname{cod}^{72}$ devin legea părţilor, iar principiul obligativităţii (pacta sunt servanda), care este specific şi materiei contractelor comerciale internaţionale ${ }^{73}$, şi cel al relativităţii, devin ambele inerente executării contractuale (odată intrat într-un astfel de contract, nu se mai poate ieşi).

Validitatea unui smart contract nu depinde de prevederile Codului civil ${ }^{74}$, ci de un consensus ${ }^{75}$ din partea celor implicaţi în reţea ${ }^{76}$, acesta fiind de tip proof of work ${ }^{77}$ sau o validare în cazul utilizării proof of stake ${ }^{78}$ (ambele sunt mecanisme stabilite pentru verificarea şi acceptarea în blockchain a tranzacţiilor).

Un minus pe care smart contracts îl prezintă este că nu oferă confidenţialitate - au caracterul de a fi distributed, împrumutat de la tehnologia blockchain pe care o utilizează. Prin urmare, toate calculatoarele din reţeaua P2P pe care se regăsesc blocks pot vedea contractul şi cum au participat părţile la acel contract (sunt publice $^{79}$, vizibile pentru toată lumea). Este adevărat că părţile din smart contracts au un pseudonim asociat, dar se susţine că în cazuri rare identitatea reală poate fi descoperită ${ }^{80}$.

Există avansată în doctrina de dreptul comerţului internaţional concepţia „autocraţiei contractuale" ${ }^{\prime 1}$, care presupune că un contract poate exista fără a avea aleasă o anumită lege aplicabilă, fiind o formă de autoreglementare şi autosuficienţă - contractul fiind suficient prin el însuşi pentru a fi eficace, a produce efecte juridice ${ }^{82}$. Concepţia nu a fost bine-primită în doctrina internaţională, opunându-i-se atât art. 3 alin. (1) şi (3) din Regulamentul Roma I ${ }^{83}$, cât şi imposibilitatea de sine stătătoare de a exista un „contract fără lege” ${ }^{44}$. Luând în

${ }^{72}$ Idem, p. 20.

${ }^{73}$ L. Tuleașcă, Dreptul comerțului internațional. Tranzacții comerciale internaționale, Editura Universul Juridic, București, 2017, p. 249.

${ }^{74}$ Legea nr. 287 din 17 iulie 2009 privind Codul civil publicată în Monitorul Oficial nr. 505 din 15 iulie 2011.

${ }^{75}$ R. Zhang, R. Xue, L. Liu, op. cit., p. 3.

${ }^{76}$ Idem, p. 3.

${ }^{77}$ Pentru mai multe detalii, a se vedea, S. Seang, D. Torre, Proof of Work and Proof of Stake consensus protocols: a blockchain application for local complementary currencies, GREDEG Working Papers 2019-24, Groupe de REcherche en Droit, Economie, Gestion (GREDEG CNRS), Université Côte d'Azur, France, [Online] la https://gdre-scpoaix.sciencesconf.org/195470/document, accesat 30.11.2021.

${ }^{78}$ Pentru mai multe detalii, a se vedea, S. Seang, D. Torre, op. cit.

${ }^{79}$ Innovation Lab (IDB Lab) of the Inter-American Development Bank, Cross-Border Payments with Blockchain, 2021, [Online] la https://publications.iadb.org/publications/ english/document/Cross-Border-Payments-with-Blockchain.pdf, accesat 30.11.2021, p. 12.

${ }^{80}$ Innovation Lab (IDB Lab) of the Inter-American Development Bank, Cross-Border Payments with Blockchain, ..., p. 13.

${ }^{81}$ L. Tuleașcă, op. cit., p. 233.

82 Ibidem.

${ }^{83}$ Regulamentul (CE) nr. 593/2008 Al Parlamentului European și al Consiliului din 17 iunie 2008 privind legea aplicabilă obligațiilor contractuale (Roma I), publicat în JO L 177, 4.7.2008.

${ }^{84}$ Ibidem. 
considerare caracterul autonom al smart contracts ${ }^{85}$, acestea ar putea valida existenţa unei autocraţii contractuale.

În cazul smart contracts, nu există neexecutare în sensul Codului civil (nu poate fi invocată excepţia de neexecutare sau executarea neconformă), ceea ce atrage lipsa unor incidente de natură litigioasă. $\mathrm{O}$ discuţie pe care smart contracts o pot ridica este existenţa sau nu a unui caracter adezionar, dar vom lăsa acest subiect pentru o lucrare viitoare.

\subsection{Utilizarea smart contracts în publicitatea comercială online}

Printre utilizările tehnologiei blockchain de până în prezent, se numără marketing-ul şi, în special, publicitatea comercială online $e^{86}$. Având în vedere particularitatea domeniului, smart contracts în publicitatea online comportă o serie de caracteristici proprii.

Pentru început, în considerarea fluxului de date care circulă între participanţii la ecosistemul publicitar, executarea unor contracte de publicitate comercială încheiate sub formă de smart contracts implică primirea tuturor informaţiilor necesare şi transmiterea lor. Prin urmare, aceste smart contracts specifice presupun utilizarea unor instrumente ce ţin de data analytics ${ }^{87}$, atât pentru furnizarea informaţiilor legate de consumatori (pentru publicitatea personalizată), cât şi pentru a obţine informaţii cu privire la rezultatele concrete ale publicităţii, în funcţie de care se stabileşte şi plăteşte automat preţul contractului. Pentru a se obţine date din afara sistemului blockchain, în special pentru verificarea executării

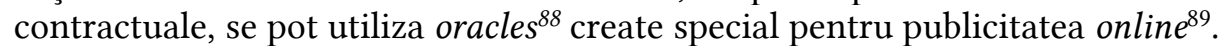

Aceste contracte ar fi afectate de o condiţie suspensivă (prealabilă ${ }^{90}$ ) constând în atingerea performanţelor (rezultatelor) specificate în contractul de publicitate comercială online. Numai ulterior verificării, prin intermediul datelor

${ }^{85}$ M. Corrales, M. Fenwick, H. Haapio, op. cit., p. 18.

${ }^{86}$ D. Jaina, M. K. Dashb, A. Kumarc, S. Luthra, op. cit., pp. 1, 2.

${ }^{87}$ Idem, p. 12.

${ }^{88}$ K. Mammadzada, F. Milani, M. Iqbal, L. García-Bañuelos, Blockchain Oracles: A Framework for Blockchain-Based Applications, în Business Process Management: Blockchain and Robotic Process Automation Forum, BPM 2020 Blockchain and RPA Forum, Seville, Spain, September 13-18, 2020, Proceedings (pp.19-34), DOI:10.1007/978-3-030-58779-6_2, [Online] la https://www.researchgate.net/ publication/344079826_Blockchain_Oracles_ A_Framework_for_Blockchain-Based_Applications, accesat 30.11.2021, p. 3. Oracles se referă în esență la servicii de tip third-party (părți „străine” de smart contract) care preiau informații din exterior (din viaţa reală) și le transmit în rețeaua blockchain. Acestea pot fi inclusiv aplicații software care „culeg” informații. Pentru mai multe detalii despre definiția oracles, a se vedea, [Online] https://en.wikipedia.org/wiki/Blockchain_oracle, accesat 30.11.2021.

${ }^{89}$ [Online] la https://www.coindesk.com/business/2021/09/23/umbrella-networkacquires-digital-advertising-oracle-lucidity-for-tens-of-millions/, https://tech.eu/features/20836/unboxed-brings-blockchain-oracles-to-aid-the-social-mediamarketing-industry/ și https://www.newsbtc.com/sponsored/satt-project-offers-smartcontracts-oracles-digital-ads/, accesat 30.11.2021.

${ }^{90}$ L. Tuleașcă, op. cit., p. 261. 
oferite de oracles, se poate face plata. Realizarea condiţiei nu ar avea efectul retroactiv din dreptul naţional ${ }^{91}$, ci efectul ex nunc prevăzut drept regulă în Principiile Unidroit ${ }^{22}$. În contractele din comerţul internaţional, constatarea îndeplinirii condiţiei se realizează frecvent prin procedura de „closing" ${ }^{\prime \prime}$, atunci când este prevăzută o dată limită pentru îndeplinirea condiţiei şi părţile se întâlnesc la acea dată pentru a constata sau nu îndeplinirea ei. Într-un smart contract, realizarea condiţiei va conduce automat la plata preţului, fără intervenţia a părţilor contractante.

În plus, prin utilizarea tehnologiei blockchain se pot elimina intermediarii de care părţile depind în realizarea plăţii contractului de publicitate încheiat între ele $^{94}$. Un astfel de intermediar poate întârzia plata contractului, poate face greşeli de calcul a preţului sau chiar modifica intenţionat statisticile în baza cărora preţul este stabilit ${ }^{95}$ şi poate săvârşi alte tipuri de fraude. În schimb, ceilalţi intermediari specifici ecosistemului publicitar (cei care fac parte din ad network sau ad exchange) nu pot fi excluşi din smart contracts, o parte din ei fiind de esenţa mecanismului publicităţii online. Particularitatea tehnologiei blockchain în contractele de publicitate comercială este că smart contracts se încheie, pe rând, între toate părţile din întreg lanţul contractual publicitar ${ }^{96}$. Totuşi, se susţine că prin intermediul smart contracts se pot înlătura anumiţi intermediari (pentru o optimizare a numărului şi rolului lor) şi se poate facilita şi o relaţie contractuală directă între publisher şi advertiser ${ }^{97}$.

În final, legat de imposibilitatea existenţei unei excepţii de neexecutare, există şi opinia conform căreia reţeaua blockchain ar opera inclusiv drept o garanţie a executării conforme a contractului ${ }^{98}$, mai ales în publicitatea comercială online, unde fraudele sunt frecvente, iar executările neconforme nu pot fi în mod tradiţional verificate şi sanç̧ionate.

91 Art. 1.407 C. civ.

${ }^{92}$ Art. 5.3.2. din Principiile Unidroit, [Online] la https://www.unidroit.org/ instruments/commercial-contracts/unidroit-principles-2016/, accesat 30.11.2021.

${ }^{93}$ L. Tuleașcă, op. cit., p. 262.

${ }^{94}$ M. Corrales, M. Fenwick, H. Haapio, op. cit., p. 5.

${ }^{95}$ SaTT Token, Smart Advertising Transaction Token (SaTT), White Paper, p. 15.

${ }^{96}$ TATA Consulting Services, Digital Advertising, Blockchain(ed), White Paper, 2017, [Online] la https://www.tcs.com/content/dam/tcs/pdf/Industries/hitech/ abstract/UsingBlockchain-Digital-Ad-Ecosystem-0817-1.pdf, accesat 30.11.2021, p. 3.

${ }^{97}$ TATA Consulting Services, Digital Advertising, Blockchain(ed), ..., p. 4.

${ }^{98}$ M. Corrales, M. Fenwick, H. Haapio, op. cit., p. 5. 


\subsection{Criptomonede drept „preţ” în smart contracts în publicitatea online. Studiu de caz: Smart Advertising Transaction Token (SaTT)}

Plata în smart contracts realizate pe o infrastructură de blockchain poate fi făcută şi în digital tokens ${ }^{99}$ (care, prin natura lor, exclud banii ${ }^{100}$ ). Prin urmare, în aceste contracte poate exista un preţ stabilit în digital tokens ${ }^{101}$, acestea având o valoare proprie şi o utilitate mai extinsă decât criptomonedele ${ }^{102}$.

În opinia noastră, digital tokens creează un mediu propice pentru comerţul internaţional întrucât favorizează plăţile transfrontaliere prin eliminarea diferenţelor de curs valutar (ele nu se raportează la nicio monedă ${ }^{103}$ naţională sau regională), rapiditatea transferului, reducerea taxelor şi a comisioanelor ${ }^{104}$ interbancare. Existând în prezent un digital token creat special pentru contractele de publicitate comercială online, se conturează premisele creşterii încheierii unor contracte internaţionale de publicitate comercială online şi pătrunderea acestora într-o proporţie din ce în ce mai mare în comerţul internaţional.

Acel digital token creat special pentru plata preţului în contractele de publicitate comercială online este Smart Advertising Transaction Token ${ }^{105}$ (SaTT). Acesta este un digital token care are la bază tehnologia blockchain, fiind creat pe

${ }^{99}$ Invao, Token Classes Explained: Coin vs. Utility Token vs. Security Token, [Online] la https://invao.org/token-classes-explained-coin-vs-utility-token-vs-security-token/, accesat 30.11.2021.

${ }^{100}$ Inland Revenue Authority of Singapore, Digital Payment Tokens, [Online] la https://www.iras.gov.sg/taxes/goods-services-tax-(gst)/specific-business-sectors/digitalpayment-tokens, accesat 30.11.2021.

${ }^{101}$ Digital tokens se referă la un echivalent digital al unui drept sau al unei valori. Un digital token poate reprezenta un drept de proprietate, poate oferi dreptul la anumite servicii sau poate reprezenta un mijloc de plată sau de schimb.

Pentru mai multe detalii, a se vedea, ING Bank, European Central Bank, Cryptocurrencies and tokens, September 2018, [Online] la https://www.ecb.europa.eu/ paym/groups/pdf/fxcg/2018/20180906/Item_2a_-_Cryptocurrencies_and_tokens.pdf,

accesat 30.11.2021, p. 5; https://uk.practicallaw.thomsonreuters.com/w-0240323? originationContext $=$ knowHow \& transitionType $=$ KnowHowItem\&contextData $=(\mathrm{sc} . \mathrm{D}$ efault)\&firstPage=true, accesat 30.11.2021.

102 Criptomonedele sunt digital tokens, dar cu o utilitate restrânsă, ele stocând o anumită valoare şi fiind utilizate în principal pentru plăți (nu şi pentru a obține un serviciu sau pentru a oferi reprezentarea digitală a unui drept de proprietate). Pentru mai multe detalii, a se vedea, ING Bank, European Central Bank, Cryptocurrencies and tokens, ..., p. 5.

${ }^{103}$ Inland Revenue Authority of Singapore, Digital Payment Tokens, [Online] la https://www.iras.gov.sg/taxes/goods-services-tax-(gst)/specific-business-sectors/digitalpayment-tokens, accesat 30.11.2021.

${ }^{104}$ Innovation Lab (IDB Lab) of the Inter-American Development Bank, Cross-Border Payments with Blockchain, ...

105 Pentru mai multe detalii, a se vedea, [Online] https://satt-token.com/, accesat 30.11.2021. 
reţeaua Ethereum ${ }^{106}$ (tranzacţiile fiind înregistrate în blocks înlănţuite în aceasta) datorită costurilor reduse şi a rapidităţii în executare ${ }^{107}$.

SaTT este reglementat de un smart contract (SaTT Smart Contract), care cuprinde clauzele contractului de publicitate online, stabilind standardele contractuale ce trebuie atinse şi remuneraţia cuvenită, care este totodată şi garantată ${ }^{108}$. In SaTT Smart contracts, plata se realizează doar dacă sunt îndeplinite condiţile stabilite de advertiser şi sunt atinse rezultatele. Advertiser-ul poate stabili inclusiv criterii ce ţin de vârsta, sexul, domiciliul, interesul utilizatorilor cărora le sunt afişate reclamele. De asemenea, el stabileşte şi caracteristicile pe care şi le doreşte pentru cocontractantul său (poate stabili, spre exemplu, un anumit nivel de influenţă pe care acesta să îl aibă $)^{109}$.

Ulterior, rezultatele executării contractului sunt furnizate drept informaţie în blockchain, prin intermediul oracles, care pot fi stabilite chiar de către advertiser prin alegerea unor anumite aplicaţii ${ }^{110}$ (spre exemplu, dacă o campanie publicitară de tip influencer marketing ${ }^{111}$ are loc pe Instagram, se poate alege o aplicaţie care măsoară performanţele acţiunilor publicitare pe Instagram). Ulterior primirii informaţiei şi verificării executării contractului, preţul pentru prestarea serviciului de publicitate online este eliberat (transferat) publisher-ului ${ }^{112}$.

SaTT poate fi folosit nu numai de publishers şi advertisers, dar şi de alţi actori implicaţi în publicitatea online, precum influencerii ${ }^{113}$. Se pot încheia smart contracts cu influencerii, acestea funcţionând în baza aceluiaşi mecanism. În fapt, SaTT a fost creat în mod special pentru creatori de conţinut ${ }^{114}$ precum influencerii. Caracterul descentralizat al tehnologiei blockchain este unul dintre avantajele oferite de utilizarea SaTT întrucât părţile implicate în contract nu trebuie să îşi acorde toată încrederea unei agenţii de publicitate, care deţine în mod exclusiv controlul şi înştiinţează ambele părţi în limita informaţiilor pe care doreşte să le furnizeze.

106 Pentru mai multe detalii, a se vedea, [Online] https://ethereum.org/en/whitepaper/ \#token-systems, accesat 30.11.2021.

107 SaTT Token, Smart Advertising Transaction Token (SaTT), White Paper, p. 4.

${ }^{108}$ SaTT Token, Smart Advertising Transaction Token (SaTT), White Paper p. 4.

${ }^{109}$ SaTT Token, Smart Advertising Transaction Token (SaTT), White Paper p. 13.

110 SaTT Token, Smart Advertising Transaction Token (SaTT), White Paper p. 14.

111 Z. Kadekova, M. Holienčinová, op. cit.

112 SaTT Token, Smart Advertising Transaction Token (SaTT), White Paper p. 13.

${ }^{113}$ Influencerii sunt acele persoane care au potențialul de a crea engagement, de a stimula conversația și/sau influența decizia de a cumpăra produse/servicii pentru un public țintă. Pentru mai multe detalii, a se vedea, IAB Romania, 2Performant, Consiliul Român pentru Publicitate, Cod de bune practici în influencer marketing, România, 2020, [Online] la https://drive.google.com/file/d/1ibPvEqUn9CtiFlo9Dc9e4iVobk rzSBxW/view, accesat 30.11.2021, p. 8.

114 [Online] la https://satt-token.com/blog/2021/09/23/satt-documentation/, accesat 30.11.2021. 
SaTT poate fi achiziţionat cu bani sau criptomonede şi, în mod simetric, poate fi transformat în bani sau în criptomonede sau poate fi utilizat pentru achiziţia unor produse ${ }^{115}$, fiind ţinut într-un portofel digital ${ }^{116}$.

Totuşi, utilizarea SaTT nu este lipsită de riscuri, cel mai mare fiind acela al existenţei şi tranzacţionării sale pe o piaţă nereglementată din punct de vedere legal, deşi la nivelul Uniunii Europene se fac paşi importanţi şi susţinuţi în această direcţie $^{117}$. În pofida lipsei reglementării, având în vedere că operaţiunile ce implică SaTT sunt bazate pe tehnologia blockchain, riscul ivirii unor litigii ar trebui să fie aproape non-existent ${ }^{118}$.

Un alt risc presupus de utilizarea SaTT este dat de dinamica şi volatilitatea ${ }^{119}$ sa în raport cu monedele clasice. În concret, am putea ajunge să ne întrebăm dacă astfel de contracte ar putea fi calificate drept aleatorii, întrucât poate avea loc oricând o depreciere radicală a valorii - la momentul încheierii contractului să stabilit fie un anumit număr fix de SaTT, cu o anumită valoare totală, iar până la executarea sa şi momentul plăţii, deşi numărul de SaTT este acelaşi, valoarea lor să fie diminuată de câteva ori, chiar aproape de 0 . O soluţie la care ne-am gândit momentan ar fi oracles care să furnizeze informaţii cu privire la flunctuaţia valorii, iar în baza acestor informaţii, algoritmul să adapteze numărul de digital tokens în funcţie de o valoare stabilită iniţial în contract prin raportare la o anumită monedă (o formă de clauză de indexare a preţului contractului sau clauză de adaptare ${ }^{120}$ specifică contractelor de comerţ internaţional). Criptomonedele, o formă de digital tokens, fac în prezent obiectul speculei ${ }^{121}$, ceea ce confirmă riscul expus.

\subsection{Executarea contractului. Rolul tehnologiei blockchain}

S-a apelat la utilizarea tehnologiei blockchain în publicitatea online pentru a asigura securitatea şi integritatea datelor în timpul executării contractului, precum şi pentru a efectua cu rapiditate şi în mod corect plata, care este verificată ${ }^{122}$ şi făcută numai după executarea conformă a contractului.

115 SaTT Token, Smart Advertising Transaction Token (SaTT), White Paper p. 22.

${ }_{116}$ Pentru mai multe detalii, a se vedea, [Online] https://satt-token.com/blog/2021/02/

19/tutorial-download-trust-wallet-and-export-your-satt-erc20-wallet/, accesat 30.11.2021.

117 Token Alliance, Chamber of Digital Commerce, Understanding Digital Tokens. Legal Landscapes Governing Digital Tokens in the European Union, May 2021, [Online] la https://4actl02jlq5u2o7ouq1ymaad-wpengine.netdna-ssl.com/wp-content/ uploads/2021/05/Legal-Landscapes-Governing-Digital-Tokens-in-the-EuropeanUnion.pdf, accesat 30.11.2021.

118 SaTT Token, Smart Advertising Transaction Token (SaTT), White Paper p. 32.

${ }^{119}$ SaTT Token, Smart Advertising Transaction Token (SaTT), White Paper p. 32.

${ }^{120}$ L. Tuleașcă, op. cit., p. 264.

${ }^{121}$ J. Silberholz. S. M. Ross, Di (A.) Wu, Measuring Utility and Speculation in Blockchain Tokens, September 1, 2021, http://dx.doi.org/10.2139/ssrn.3915269, [Online] la https://papers.ssrn.com/sol3/papers.cfm?abstract_id=3915269, accesat 30.11.2021, p. 2.

${ }^{122}$ SaTT Token, Smart Advertising Transaction Token (SaTT), White Paper p. 4. 
Pentru executarea contractului, o etapă importantă este consensus mechanism $^{123}$. Acesta reprezintă un algoritm, poate fi de tip proof of work sau proof of stake (v. supra), iar prin intermediul său se verifică dacă obligaţia a fost executată astfel cum s-a specificat contractual (dacă reclamele au fost afişate în spaţiile online unde s-a stabilit şi dacă afişarea a fost făcută unor consumatori cu anumite specificaţii, cu o anumită valoare sau chiar unor consumatori care au interacţionat cu conţinutul). Dacă în urma verificării reiese că executarea a fost conformă, datele vor fi înregistrate în block. Dacă nu, va fi ca şi cum nu ar fi fost niciodată executată obligaţia, iar plata nu va fi realizată.

Astfel cum am arătat, preţul ar fi stabilit drept o formulă ${ }^{124}$ în contractele de publicitate comercială online. Conţinutul său implică variabile constând în rezultatele pe care reclamele le au. Aceste date sunt obţinute prin intermediul oracles, care furnizează doar date reale, autentice, cu privire la performanţele reclamelor (fiind excluse ad frauds). Datele oferite de oracles au un rol important şi în verificarea executării contractuale conforme.

De îndată ce executarea este verificată şi se califică drept conformă, plata se realizează automat, rapid, în baza calculului efectuat. Astfel, orice neînţelegere sau chiar litigiu cu privire la neexecutările contractuale, în special cele referitoare la plata preţului, ar deveni de domeniul trecutului ${ }^{125}$ cu ajutorul smart contracts.

Toate datele cu privire la executare sau necesare executării (mai ales rezultatele reclamelor) sunt stocate într-o manieră ce asigură integralitatea şi securitatea lor, existând posibilitatea de a fi accesate şi verificate ulterior, fără a le afecta.

\subsection{Avantajele şi dezavantajele utilizării tehnologiei blockchain}

Pentru început, publicitatea online are rolul de a susţine $e$-commerce ${ }^{126}$, astfel că orice element care vine spre a încuraja şi facilita încheierea şi executarea contractelor de publicitate comercială online, reprezintă şi un impuls pentru comerţul online. În cele ce urmează, vom arăta că utilizarea tehnologiei blockchain în publicitatea comercială online se prefigurează drept un suport contractual eficient şi benefic încheierii şi executării contractelor.

În primul rând, tehnologia blockchain preîntâmpină frauda în publicitatea online $^{127}$, ceea ce conduce la o reducere a prejudiciilor suferite de către profesioniştii ale căror produse sunt promovate prin publicitatea online. Aceasta este prin ea însăşi un simbol al încrederii, ceea ce exclude $a b$ initio forme de înşelăciune/fraudă, sub toate „impersonările” sale expuse într-o secţiune precedentă.

${ }^{123}$ B. Lashkari, P. Musilek, A Comprehensive Review of Blockchain Consensus Mechanisms, în IEEE Access PP(99): 1-1, DOI: https://doi.org/10.1109/ACCESS.2021.3065880, [Online] la https://www.researchgate.net/publication/350031088_A_Comprehensive_Review_of_Bloc kchain_Consensus_Mechanisms, accesat 30.11.2021, p. 3.

${ }^{124}$ PwC, Is blockchain the answer to digital advertising's trust gap?, ..., p. 5.

${ }^{125} \mathrm{PwC}$, Is blockchain the answer to digital advertising's trust gap?, ..., p. 5.

${ }^{126}$ D. Jaina, M. K. Dashb, A. Kumarc, S. Luthra, op. cit., p. 8.

${ }^{127}$ Idem, p. 11. 
Acţiunile boţilor şi folosirea click farms ar fi preîntâmpinate ${ }^{128}$. De asemenea, tehnologia blockchain poate urmări digital locaţia afişării unei reclame şi verifica legitimitatea site-ului în cauză ${ }^{129}$.

Tehnologia blockchain contribuie şi la eficientizarea prestării serviciilor de publicitate online, întrucât implică utilizarea unor date obţinute în timp real, date de încredere, iar în baza acestora consumatorii din mediul online ar fi expuşi unor reclame cu un grad mai mare de relevanţă pentru ei, bucurându-se în acelaşi timp şi de un grad ridicat de protecţie a datelor cu caracter personal ${ }^{130}$. De asemenea, şi un content creator implicat în campania publicitară poate alege campaniile potrivite pentru el, cele mai relevante şi profitabile ${ }^{131}$ şi e sigur că dacă execută contractul conform specificaţiilor, va primi plata integrală fără întârzieri nejustificate.

Întregul ecosistem devine mai simplu, transparent şi rapid ${ }^{132}$, executarea contractelor prin tehnologia blockchain realizându-se non-stop ${ }^{133}$. Orice fel de breşă de securitate a datelor este aproape imposibilă atunci când se utilizează această tehnologie ${ }^{134}$. În plus, blockchain acţionează şi la nivelul încrederii consumatorilor ${ }^{135}$, asigurând creşterea sa.

Apelarea la blockchain reduce costurile totale ale contractelor care erau încheiate prin intermediari ${ }^{136}$ bancari, dar adesea sunt percepute comisioane de către cei care administrează rețeaua (o formă de remuneraţie pentru utilizarea infrastructurii blockchain). La nivel probatoriu, datorită caracterului imuabil, irevocabil şi permament, smart contracts fac dovada atât a contractului, cât şi a plăţii ${ }^{137}$, ele fiind uşor de idenfiticat prin hash-ul block-ului ${ }^{138}$.

În final, tot în privinţa avantajelor, informaţiile generate de tranzacţii sunt vizibile doar persoanelor care au acces în blocks, ceea ce înseamnă că sunt protejate împotriva accesului neautorizat sau activităţilor ilicite, dar îşi păstrează totodată şi caracterul public faţă de ceilelalte părţi din blockchain (ceea ce contribuie la un anumit grad de transparenţă).

$\mathrm{Cu}$ privire la dezavantaje, din punct de vedere al prevederilor Regulamentului general privind protecţia datelor ${ }^{139}$, tehnologia blockchain, în special cea

${ }^{128} \mathrm{PwC}$, Is blockchain the answer to digital advertising's trust gap?, ..., p. 5.

${ }^{129}$ Ibidem.

${ }^{130}$ Idem, p. 2.

${ }^{131}$ SaTT Token, Smart Advertising Transaction Token (SaTT), White Paper p. 19.

${ }^{132} \mathrm{PwC}$, Is blockchain the answer to digital advertising's trust gap?, ..., p. 5.

133 M. Corrales, M. Fenwick, H. Haapio, op. cit., p. 5.

${ }^{134} \mathrm{PwC}$, Is blockchain the answer to digital advertising's trust gap?, ..., p. 5.

${ }^{135}$ D. Jaina, M. K. Dashb, A. Kumarc, S. Luthra, op. cit., p. 12.

${ }^{136}$ M. Corrales, M. Fenwick, H. Haapio, op. cit., p. 5.

${ }^{137}$ Innovation Lab (IDB Lab) of the Inter-American Development Bank, Cross-Border Payments with Blockchain, ..., p. 48.

138 D. Jaina, M. K. Dashb, A. Kumarc, S. Luthra, op. cit., p. 2.

${ }^{139}$ Regulamentul (UE) 2016/679 al Parlamentului European și al Consiliului din 27 aprilie 2016 privind protecția persoanelor fizice în ceea ce privește prelucrarea datelor cu caracter personal și privind libera circulaţie a acestor date și de abrogare a Directivei 
publică ${ }^{140}$, nu îndeplineşte integral condiţiile de prelucrare a datelor cu caracter personal impuse de acesta, mai ales în ceea ce priveşte reducerea la minimum a datelor, limitarea perioadei de stocare şi principiul exactităţii, întrucât datele sunt stocate pe o perioadă nelimitată ${ }^{141}$, iar dacă sunt incomplete sau incorecte nu pot fi modificate etc.

Deşi securitatea contractuală este garantată, securitatea infrastructurii blockchain nu are o siguranţă de $100 \%$, existând o încercare de fraudă şi în $2018^{142}$. Nefiind reglementat, nici în zona Uniuniii Europene ${ }^{143}$, existenţa unor fraude sau erori în blockchain nu ar putea fi reparate prin tragerea la răspundere şi repararea prejudiciului. Riscurile provin din faptul că încă nu se cunosc toate implicaţiile juridice. plată ${ }^{144}$.

Un ultim dezavantaj este reprezentat de lipsa standadizării în materie de

\section{Concluzii}

Automatizarea executării contractuale este specifică noilor tehnologii care îşi fac simţită prezenţa în domeniul juridic. Pe măsură ce acestea sunt dezvoltate, aplicabilitatea lor va deveni din ce mai extinsă, peisajul juridic urmând a fi profund transformat. Parte din noile tehnologii este şi blockchain-ul, care se prefigurează drept un mijloc de modernizare, eficientizare, securizare şi transparentizare a ecosistemului publicitar. Fiind deja implementată, deşi nu la scară largă, aceasta pare să fi avut succes până în prezent, întrucât în urma unei lungi şi detaliate analize a doctrinei existente, nu am regăsit a fi ridicate probleme din practică în legătură cu smart contracts în publicitatea comercială online.

Tehnologia blockchain se conturează drept o soluţie pentru una dintre cele mai mari şi acute probleme ale publicităţii comerciale online, şi anume frauda în executarea contractuală. Din cercetarea realizată, reiese că ar avea chiar potenţialul de a o elimina complet, ceea ce ar conduce la sume mai mari alocate unui marketing de calitate (calitatea fiind dată de executarea conformă fără de care plata nu poate fi realizată).

La momentul actual, industria publicităţii online are un potenţial prejudiciator pentru toţi actorii implicaţi, în parte şi din cauza intervenţiei factorului uman.

95/46/CE (Regulamentul general privind protecția datelor) (Text cu relevanță pentru SEE), OJ L 119, 4.5.2016, pp. 1-88.

${ }^{140}$ A. Wallace, Protection of Personal Data in Blockchain Technology. An investigation on the compatibility of the General Data Protection Regulation and the public blockchain, Master's Thesis, 2018, [Online] la https:/www.diva-portal.org/smash/get/diva2:1298747/ FULLTEXT01.pdf, accesat 30.11.2021, p. 48.

${ }^{141}$ Idem, p. 47.

${ }^{142}$ Pentru mai multe detalii, a se vedea, [Online] https://www.forbes.com/sites/ thomasbrewster/2019/01/23/ether-scammers-made-36-million-in-2018double-their-2017winnings/, accesat 30.11.2021.

${ }^{143}$ SaTT Token, Smart Advertising Transaction Token (SaTT), White Paper, p. 32

${ }^{144}$ ING Bank, European Central Bank, Cryptocurrencies and tokens, September 2018, ..., p. 8. 
Astfel, adiacent subminării fraudei, tehnologia blockchain contribuie, prin automatizare, atât la creşterea încrederii părţilor contractuale în executarea contractului, cât şi la creșterea încrederii consumatorilor. În acest mod, se va ajunge la o creştere şi mai susţinută a industriei publicităţii online, atingând o dimensiune chiar astronomică ${ }^{145}$, care ar leza mai puţin interesele profesioniştilor şi ale consumatorilor. Existenţa neexecutării, precum şi a litigiilor, nu îşi vor mai avea locul în smart contracts.

Tehnologia blockchain va aduce cu sine o schimbare a ecosistemului publicitar în principal prin modificarea numărului participanţilor implicaţi şi prin naşterea unor noi modalităţi de stabilire şi plată a preţului. Apariţia unor viitoare reglementări în domeniu vor putea să diminueze dezavantajele pe care utilizarea tehnologiei blockchain în publicitatea comercială online le prezintă momentan.

\section{Referinţe}

Atzori M., Sistemi I., Blockchain technology and decentralized governance: Is the state still necessary?, în Journal of Governance and Regulation 6(1), March 2017, DOI: https://doi.org/10.22495/jgr_v6_i1_p5

Bleier A., Eisenbeiss M., Personalized Online Advertising Effectiveness: The Interplay of What, When, and Where, July 2015, Marketing Science, 2015, DOI: https://doi.org/ 10.1287/mksc.2015.0930

Corrales M., Fenwick M., Haapio H., Digital Technologies, Legal Design and the Future of the Legal Profession în M. Corrales, M. Fenwick, H. Haapio (eds.), Legal tech, Smart contracts and Blockchain, Springer Nature Singapore Pte Ltd., 2019

Daswani N., Mysen C., Rao V., Weis S., Gharachorloo K., Ghosemajumder S., the Google Ad Traffic Quality Team, Online Advertising Fraud, 2007

Išoraitè M., Raising Brand Awarenees Through The Internet Marketing Tools, în Independent Journal of Management \& Production (IJM\&P), v. 7, n. 2, April - June 2016, DOI: https://doi.org/10.14807/ijmp.v7i2.39

Jain A., Khan S., Optimizing Cost per Click for Digital Advertising Campaigns, în Lattice, Volume 2, Issue 2, 2021

Jaina D., Dashb M. K., Kumarc A., Luthra S., How is Blockchain used in marketing: A review and research agenda, în International Journal of Information Management Data Insights, DOI: https://doi.org/10.1016/j.jjimei.2021.100044

Kadekova Z., Holienčinová M., Influencer marketing as a modern phenomenon creating a new frontier of virtual opportunities în Communication Today, no. 9, 2018

Koen P., Reibstein D., Challenges in Measuring Return on Marketing Investment: Combining Research and Practice Perspectives, Review of Marketing Research vol. 6. Emerald Group Publishing Limited, Bingley, 2009, DOI: https://doi.org/10.1108/S15486435(2009)0000006009

Lashkari B., Musilek P., A Comprehensive Review of Blockchain Consensus Mechanisms, în IEEE Access PP(99): 1-1, DOI: https://doi.org/10.1109/ACCESS.2021.3065880

Mammadzada K., Milani F., Iqbal M., García-Bañuelos L., Blockchain Oracles: A Framework for Blockchain-Based Applications, în Business Process Management: Blockchain and Robotic Process Automation Forum, BPM 2020 Blockchain and RPA Forum, Seville, Spain, September 13-18, 2020, Proceedings (pp.19-34), DOI: https://doi.org/10.1007/9783-030-58779-6 2

${ }^{145} \mathrm{PwC}$, Is blockchain the answer to digital advertising's trust gap?, ..., p. 6. 
Muthukrishnan S., Ad Exchanges: Research Issues, în Leonardi S. (eds), Internet and Network Economics, WINE, Lecture Notes in Computer Science, vol 5929. Springer, Berlin, Heidelberg, 2009, DOI: https://doi.org/10.1007/978-3-642-10841-9_1

Nazerzadeh H., Saberi A., Vohra R., Dynamic Cost-Per-Action Mechanisms and Applications to Online Advertising, în Internet Monetization - Online Advertising, April 21-25, Beijing, China, 2008

Pooranian Z., Conti M., Haddadi H., Tafazolli R., Online Advertising Security: Issues, Taxonomy, and Future Directions, în IEEE Communications Surveys \& Tutorials, vol. XX, vo. NN, XX, 2020

Rawat D. B., Vijay Chaudhary V., Doku R. , Blockchain Technology: Emerging Applications and Use Cases for Secure and Trustworthy Smart Systems, în Journal of Cybersecurity and Privacy no. 1(1), 2021

Seang S., Torre D., Proof of Work and Proof of Stake consensus protocols: a blockchain application for local complementary currencies, GREDEG Working Papers 2019-24, Groupe de REcherche en Droit, Economie, Gestion (GREDEG CNRS), Université Côte d'Azur, France

Silberholz J., Ross S. M., Wu Di (A.), Measuring Utility and Speculation in Blockchain Tokens, September 1, 2021, DOI: http://dx.doi.org/10.2139/ssrn.3915269

Tuleaşcă L., Dreptul comerţului internaţional. Tranzacţii comerciale internaţionale, Editura Universul Juridic, Bucureşti, 2017

Ungureanu C. T., Drept international privat european in raporturi de comert international, Editura Hamangiu, Bucureşti, 2021, p. 37

Ungureanu C. T., Toader A. I., Drept civil. Partea generală. Persoanele, Editura Hamangiu, Bucureşti, 2019

Ungureanu C. T., Dreptul comerţului internaţional, Editura Hamangiu, Bucureşti, 2018

Wallace A., Protection of Personal Data in Blockchain Technology. An investigation on the compatibility of the General Data Protection Regulation and the public blockchain, Master's Thesis, 2018

Zamfir M., Manea M., Ionescu L., Return On Investment - Indicator for Measuring the Profitability of Invested Capital, în Valahian Journal of Economic Sciences vol. 7(2), 2016, DOI: https://doi.org/10.1515/vjes-2016-0010

Zeropark Blog, What Is the Difference Between CPM, CPC, CPL, CPA and Other Performance Marketing Pricing Models?, 28th of May, 2021

Zhang R., Xue R., Liu L., Security and Privacy on Blockchain în ACM Comput. Surv. 1, 1, Article 1, January, DOI: https://doi.org/10.1145/3316481

European Parliament, Online advertising: the impact of targeted advertising on advertisers, market access and consumer choice, Study Requested by the IMCO committee, June 2021, DOI: https://doi.org/10.2861/80 | QA-02-21-683-EN-N

IAB Romania, 2Performant, Consiliul Român pentru Publicitate, Cod de bune practici în influencer marketing, România, 2020, [Online]

Inland Revenue Authority of Singapore, Digital Payment Tokens, [Online]

Innovation Lab (IDB Lab) of the Inter-American Development Bank, Cross-Border Payments with Blockchain, 2021, [Online]

Content Strategy Studio, Brand Engagement in the Participation Age, Whitepaper, February 2014 , [Online]

ING Bank, European Central Bank, Cryptocurrencies and tokens, September 2018, [Online]

Invao, Token Classes Explained: Coin vs. Utility Token vs. Security Token, [Online]

Kenton W., Cost Per Thousand (CPM), Investopedia, October 29, 2020, [Online]

MoPub Inc., Understanding ad networks, 2017, [Online] 
Open X, Ad networks vs ad exchanges: how they stack up, 2010, [Online]

$\mathrm{PwC}$, Is blockchain the answer to digital advertising's trust gap?, 2019, [Online]

PwC, Macrotrends. Global revenue - growth by segments, [Online]

TATA Consulting Services, Digital Advertising, Blockchain(ed), White Paper, 2017, [Online]

Token Alliance, Chamber of Digital Commerce, Understanding Digital Tokens. Legal Landscapes Governing Digital Tokens in the European Union, May 2021, [Online] 